\title{
Vulnerability in adolescence: a case report of attempted abortion and sexual violence
}

\author{
Adna Thaysa Marcial da Silva, Guilherme Dias de Sousa, Camila Lohmann Menezes, \\ Edson Santos Ferreira Filho, Walter da Silva Pinheiro, José Maria Soares Júnior, \\ Edmund Chada Baracat, Isabel Cristina Esposito Sorpreso
}

DOI:http://dx.doi.org/10.7322/jhgd.127686

\begin{abstract}
Introduction: Abortion, even when provided by law in cases of sexual violence, continues to be practiced in an insecure way, since women who suffer violence are not reported or guarded by social, institutional or age vulnerability, as in adolescence.

Objective: Describe the clinical consequences of unsafe abortion, report this experience as well as sexual violence in situations of social and age vulnerability.

Methods: It is a clinical case report, with the consent of the patient, in the year 2016, of a 16-year-old female adolescent with a personal history of sexual violence by an intimate aggressor. Admitted to the health service with diagnosis of acute abdomen and induced abortion using antibiotic therapy.

Results: Laboratory tests revealed altered $\mathrm{C}$ reactive protein and presence of leukocytosis, ultrasound showed heterogenic mass, computed tomography showed presence of cylindrical foreign body in vaginal cavity, surgical interventions, sepsis, clinical complications (pulmonary thromboembolism) and prolonged hospitalization.

Conclusion: The history of violence portrayed in this study reveals an attempt of abortion with self harm, revealing negative clinical repercussions and the health problems of the adolescent. This person has committed an abortion that does not fit into the abortion criteria provided by law. It also revealed the need for further discussion on the topic, highlighting health promotion practices against unsafe abortion.
\end{abstract}

Keywords: abortion, sexual violence, adolescence, septic abortion.

\section{INTRODUCTION}

The World Health Organization (WHO) shows an increase in rates of unwanted pregnancies, unsafe abortions, sexually transmitted diseases and neonatal repercussions in women who are sexually abused ${ }^{1}$. In Brazilian public health, this has a negative effect on the economy, which can vary up to $2 \%$ of GDP (gross domestic prod$\mathrm{uct})^{2}$, as well as maternal consequences related to the morbidity and mortality of our women ${ }^{3-5}$.

Unsafe abortion appears as an alternative to unwanted pregnancies ${ }^{1,6,7}$, mainly in cases related to physical violence, sexual violence, usually caused by an intimate or known partner. In such cases, abortion would be pro- vided by law in some countries ${ }^{3,6}$, but patients who suffer violence do not report or hide for various vulnerabilities -age, social and institutional ${ }^{8-10}$.

Sexual abuse ${ }^{11}$ during adolescence is a traumatic experience that complicates young women's psycho-social development at the threshold of adulthood ${ }^{2}$, resulting in consequences associated with sexually transmitted diseases, pregnancy followed by violence, unwanted pregnancies, psychosocial repercussions ${ }^{7}$ and negative sequel e that compromise reproductive health and sexual ${ }^{1}$.

The association between violence and unsafe abortion causes a risk of death ${ }^{2,5}$ in young women, related to infections, $40 \%$ of which reaches the upper genital tract $^{12}$ and sepsis ${ }^{3,6}$. Studies show the importance of early inter-

\footnotetext{
1 Nursing. Pos Graduation Obstetric and Gynecology Department, Medicine School, São Paulo University - São Paulo (SP) - Brazil.

2 Laboratory of Study Design and Scientific Writing, ABC Medical School - São Paulo (SP) - Brazil.

3 Medicine School, São Paulo University - São Paulo (SP) - Brazil.

4 Discipline of Gynecology, Hospital das Clínicas, Medicine School, São Paulo University - São Paulo (SP) - Brazil. Corresponding author: Adna Thaysa Marcial da Silva - E-mail: adnathaysa@hotmail.com
} 
vention and the interdisciplinary approach in health services to reduce the harm caused ${ }^{13}$.

Thus, reinforcing the importance of health promotion practices, the article reports a case report of a teenager with a personal history of sexual violence who performed an unsafe abortion and aims to describe the clinical consequences of unsafe abortion, report this experience as well as sexual violence in situations of social exclusion and vulnerability of age.

\section{CASE REPORT}

Identification: 16- year-old female, brown, born and raised in São Paulo - SP, incomplete high school, single and lives with her mother.

Main complaint and duration: Patient referred from the outpatient for Victims of Sexual Assault to the Gynecology Discipline, Hospital das Clínicas, Medicine School, São Paulo University, because of abdominal pain for 10 days.

Previous history of the current medical condition: Patient reporting abdominal pain in the hypogastric region for 10 days, dysuria and diarrhea with soft stools with no change in color and no bleeding associated. At the time of initial care, she was on antibiotic therapy (norfloxacin) for 6 days, without clinical improvement. She denied fever, nausea, vomiting or polaciuria.

Family history: No heart diseases, neoplasia, gynecopathies, chronic or infectious diseases were reported.

Personal history: No previous surgeries, clinical admissions, preexisting diseases, cardiopathies, neoplasia, gynecopathies, chronic, infectious diseases and sexually transmitted diseases were reported.

Habits: Smoking, alcoholism, drug use or medication were denied.

Gynecologic background: Menarche at 11 years old. First sexual intercourse at 12 years. Sexual abuse from the stepfather (husband of her mother) when she was 13 years old, follow up with an interdisciplinary approach with psychologists and infectologists. No use of contraceptive method. At the moment, she mentioned only consented sexual intercourse, last sexual intercourse 2 years ago.
General admission physical examination: Regular general condition, flushed, hydrated, feverish (axillary temperature: $37.8^{\circ} \mathrm{C}$ ), tachycardic (heart rate: 124 beats per minute - bpm), normotensive, euphonic. Cardiac and pulmonary auscultation with no relevant findings. Abdomen discretely distended, diffusely painful, especially in left iliac fossa, without worsening of pain to sudden decompression (negative Blumberg sign).

Gynecological exam: Genitalia with female appearance, trophism and pilification suitable for the age, without lesions. Specular examination was difficulted by patient's pain, identified only yellowish and fetid secretion with the presence of an injury in the proximal third of the vagina, which precluded the visualization of the cervix. At the bimanual vaginal examination, a lesion was noticed in the proximal third of the vagina, possibly stenosing, that precluded palpation of the cervix. There was important pain on the palpation of the fornices, cervix mobilization and adnexal assessment.

Complementary diagnostic tests: Full blood count, Creactive protein, serology for syphilis, hepatitis $\mathrm{B}$ and $\mathrm{C}$ and HIV, urinalysis, urinary examination of pregnancy, pelvic ultrasonography and pelvic tomography were requested.

Diagnostic hypothesis: Infectious acute abdomen and Self-inducted and insecure abortion.

Therapeutic plan: Due to sepsis and acute inflammatory abdomen, patient was hospitalized for broadspectrum intravenous antibiotic therapy (clindamycin and gentamicin) for 10 days, clinical support and diagnostic elucidation.

Results of laboratory tests: The exams showed leukocytosis and presence of toxic granulations, elevated $\mathrm{C}$ reactive protein; serological tests for syphilis, HIV, hepatitis B and C were negative. Urinary examination was negative for pregnancy.

Results of imaging tests: Pelvic ultrasonography (transabdominal technique, since transvaginal study was not possible due to patient's pain) showed a large heterogeneous mass, containing cystic areas with debris of permeation, occupying hypogastrium and left iliac fossa (Fig-

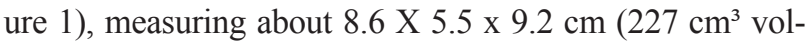
ume), with peripheral vascularization to the Doppler study (Figure 2); uterus and ovaries could not be characterized.

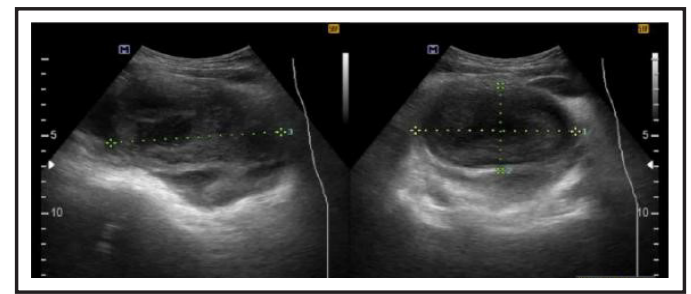

Figure 1: Pelvic ultrasonography: heterogeneous mass with $227 \mathrm{~cm}^{3}$ volume

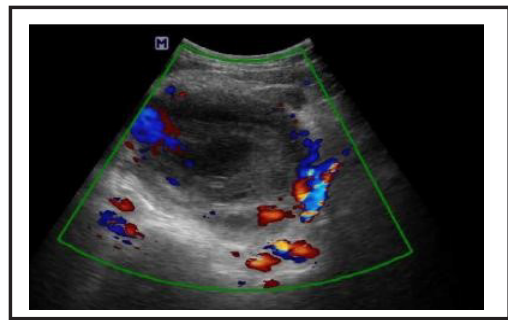

Figure 2: Pelvic Ultrasonography: Heterogeneous mass with peripheral vascularization to Doppler study 
Computed tomography of abdomen and pelvis showed a cylindrical foreign body located in the vaginal cavity, of low attenuation and with a component of internal metallic attenuation that presents intimate contact with the cervix of the uterus, about $5.0 \mathrm{~cm}$ long and $3.0 \mathrm{~cm}$ maximum diameter. In addition, a voluminous multi septate collection with walls that undergo post-contrast enhancement, located in the left adnexal region, extended to the umbilical scar, in contact with the vagina, uterus, ovaries and urinary bladder, shifting them, measuring about $12,2 \times 11.6 \mathrm{x}$
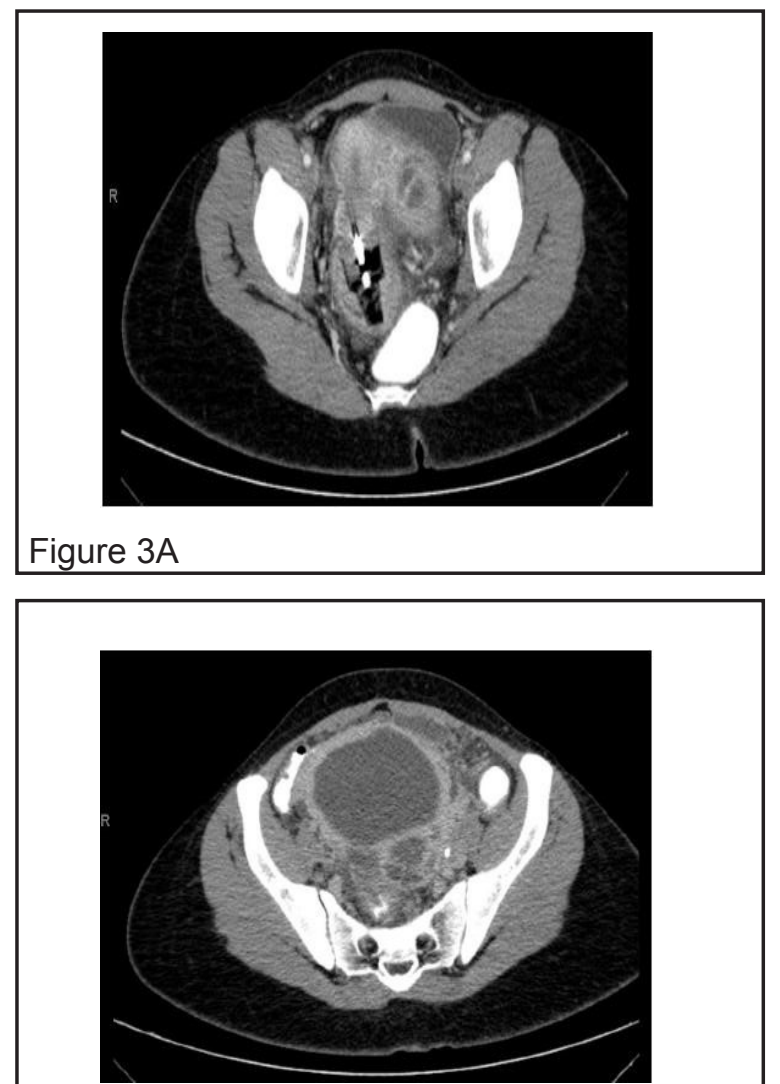

Figure 3C

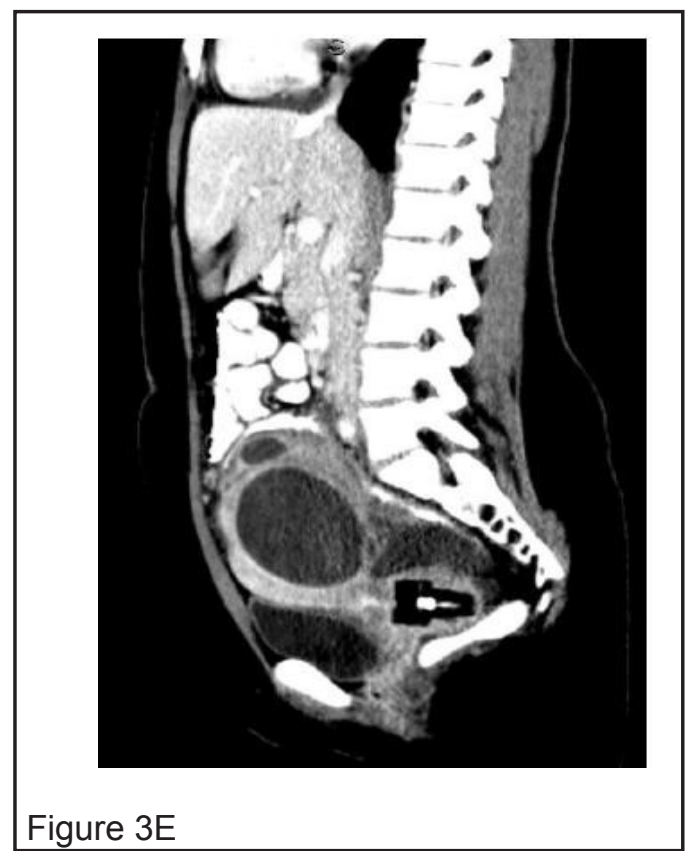

$9.7 \mathrm{~cm}$. These findings could probably represent salpingitis and left oviduct abscess (Figure 3A, 3B, 3C, $3 \mathrm{D}, 3 \mathrm{E}$ and $3 \mathrm{~F})$.

Figure 3 (3A, 3B, 3C, 3D, 3E and 3F sequences) - Computed tomography of abdomen and pelvis: a cylindrical foreign body in the vaginal cavity, a metal attenuated component that presents close contact with the uterine cervix, 5,0 cm of extension and 3,0 cm of maximum diameter; Voluminous multi septate collection with walls that undergo post-contrast enhancement, located on the left adnexa.
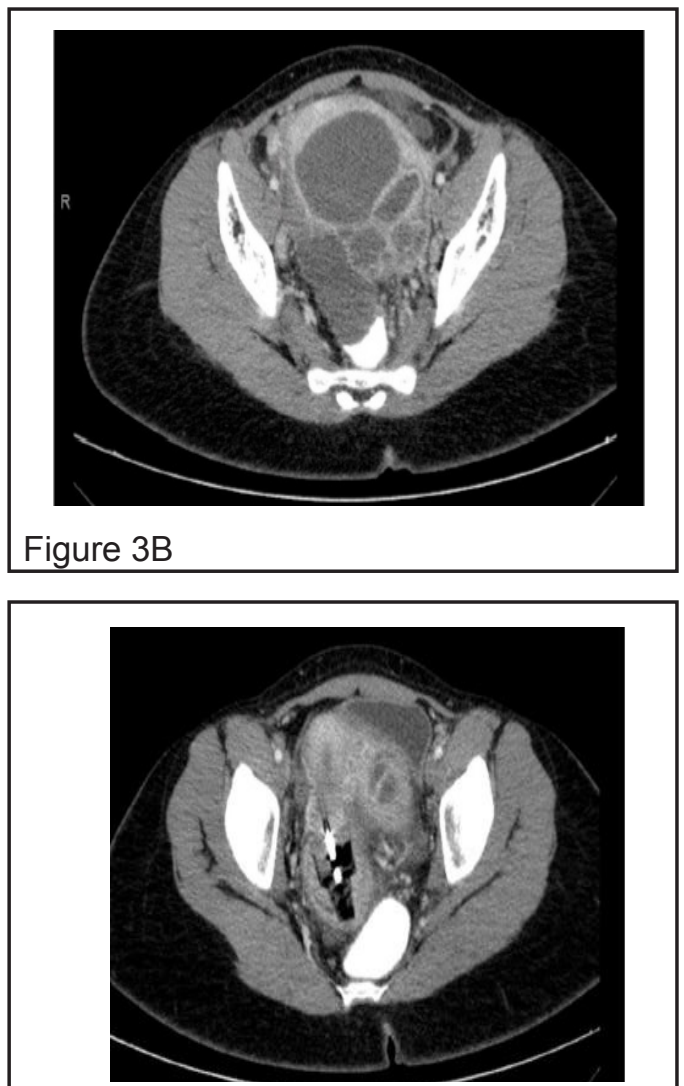

Figure 3D

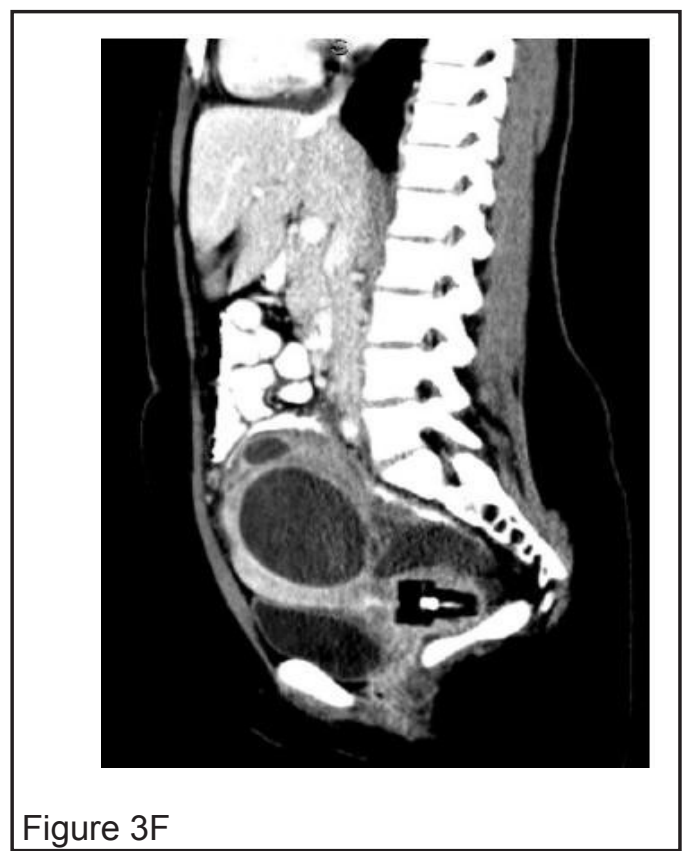




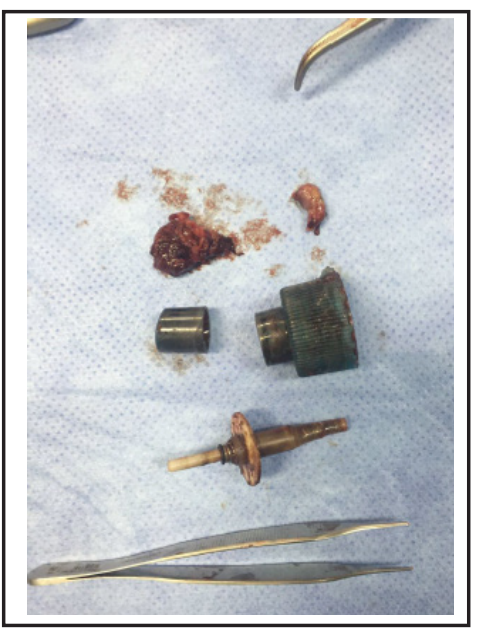

Figure 4: Foreign, cylindrical, plastic body, measuring $5.5 \times 2.8 \times 2.8 \mathrm{~cm}$, composed of three parts, removed from the upper third of the vagina

The patient has up to $37.7^{\circ} \mathrm{C}$ and slightly tachycardic (up to $115 \mathrm{bpm}$ ); because of unsatisfactory clinical response, antimicrobial scheme was modified for ceftriaxone and metronidazole and surgical approach was indicated.

Surgical approach: Patient was submitted to dissolution of vaginal stenosis and removal of foreign tissue (Figure 4) via the vagina, in a surgical room, on the third day of hospital stay, under spinal anesthesia, without complications. All tissue removed was referred for histopathological analysis. Pathologic analysis revealed Malpighian mucosa with extensive acute inflammatory infiltrate, ulcerated, extending to the submucosa, associated with granulation tissue, fibrin and necrosis.

Due to the age of the patient and, until then, absence of clinical worsening, conservative management was attempted and percutaneous drainage of pelvic abscess through interventional radiology was programmed. However, on the first postoperative day, there was worsening of tachycardia (125 bpm) and lowering of the level of consciousness, characterizing severe sepsis, as well as signs of peritonitis (Blumberg positive signal) (Figure 4).

Antibiotic therapy was modified for piperacillin / tazobactam and vancomycin and xploratory laparotomy was indicated. Mild infraumbilical laparotomy was performed under general anesthesia on the fourth hospitalization day. Inventory of the cavity: purulent free liquid in the abdominopelvic cavity, where four abscess stores were found, the largest in tubeovarian topography on the left, with multiple adhesions with omentum, small intestine, colon and ovaries. The abscesses were drained, the capsules were resected and the cavity was repeatedly washed with saline solution. Due to the degree of impairment, it was necessary to resect part of the omentum contiguous to the abscess capsules. At the end of surgery, a suction drain closed system (Portovac) was left. All removed material was referred for histopathological study, which identified: acute suppurative inflammatory process with exuberant granulation tissue in connective and adipose tissueon the abscess capsule; and exuberant acute suppurative inflammatory process in adipose tissueon the omentum.
Immediate postoperative period: In the immediate postoperative period, the patient was referred to the intensive care unit, due to the possibility of hemodynamic instability and necessity of vasoactive drug, a central venous catheter was placed in left subclavian vein.

Intensive Care Unit: The patient evolved with hemopneumothorax, drained without complications, and acute renal failure. The dose was corrected perserum levels of vancomycin. She required norepinephrine and hemotransfusion (red blood cells) to maintain hemodynamic stability for one day, evolving with partial clinical improvement. Abdominal and thoracic drains evolved with reduction of flow, thoracic drainage was removed after three days; diet acceptance and laboratory parameters for infection improved. After eight days in the Intensive Care Unit, she was referred to the ward.

Ward: followed in with intravenous antibiotic therapy and with physical therapy support. After four days, the patient evolved with progressive worsening of the respiratory pattern and underwent chest angiotomography, which revealed: failure to fill the right inferior lobar artery and its proximal basal segmental branches, compatible with acute pulmonary thromboembolism, and laminar and subsegmental atelectasis in the low pulmonary lobes. Full anticoagulation was performed with enoxaparin and warfarin until INR adjustment. Finally, she evolved with important clinical improvement.

Hospital discharge: After 42 days of hospitalization, the patient was discharged asymptomatic, taking warfarin and scheduled outpatient clinic (gynecology, gynecology, and psychiatry).

Outpatient clinic follow-up: After 20 days of hospital discharge, the patient returned to the Gynecology outpatient clinic in good clinical conditions and adequate adherence to the anticoagulant treatment. Reversible longterm contraceptive options were discussed, patient refused any options now.

In private, alone in the office, the patient informed the medical staff that she herself inserted the foreign body for induction of abortion, because she had a delayed menstrual period and feared being pregnant. She also mentioned the absence of sexual activity. The patient will return for periodic clinical and psychological assessment.

\section{DISCUSSION}

The article reports a clinical case of adolescents with a history of sexual violence, that performed an unsafe abortion causing damages and health problems. The consequences were surgical interventions, generalized infections (sepsis), clinical intercurrences such as pulmonary thromboembolism and prolonged hospitalization.

Post-abortion hospital admission rates are high and make abortion unsafe as a public health problem in Brazi $^{14,15}$ and it accounts for $13 \%$ of maternal mortality worldwide ${ }^{5,9}$. About half of women who had abortions received care in the health system and were hospitalized for complications ${ }^{16,17}$.

Considered a persistent and preventable pandemic world wide ${ }^{6,15,16}$, unsafe abortion ${ }^{17}$ places women at risk in 
developing countries where abortion is highly restricted by law or, although legally permitted as in Brazil in cases of pregnancy resulting from rape, when there is no other means of saving the life of the mother ${ }^{18}$, safe abortion is not easily accessible 6 .

In such settings, faced with an unwanted pregnancy, women often induce abortion or obtain clandestine abortions from doctors, paramedics, or traditional healers ${ }^{1}$. In our clinical case, for example, the insertion of the foreign body through the cervix had the objective of interrupting an unwanted pregnancy, where only exams that did not confirm gestation were performed in the health service.

A Brazilian study in public health showed that $15 \%$ of women induced abortion throughout the reproductive life, being the adolescence life span the most frequent ${ }^{15,16,18}$. Adolescents have priority in public health policies in Brazil ${ }^{12,17}$ and are considered vulnerable by the age group (under 14 years) and also by social and emotional dependence ${ }^{2,19,20}$ and it is the joint responsibility of health managers ${ }^{2,7}$ to facilitate access to safe abortion services in cases of pregnancy resulting from rape, when there is no other way to save the mother's life ${ }^{18}$, as well as increase social awareness ${ }^{4,16}$.

Veiled sexual violence ${ }^{11,20}$ in childhood and adolescence is related to unsafe abortion ${ }^{7,17}$.

In Brazil, there is a report of sexual violence against female children and adolescents ${ }^{12,16,17}$ with consequent unplanned pregnancies ${ }^{20}$ followed by violence. The abortion $^{7,15}$ remains a clandestine practice, especially in the context of Latin America ${ }^{21,22}$.

The reduction in the incidence of unsafe abortion is associated with the reduction in the incidence of sexual violence especially from the intimate partner ${ }^{17,23}$. In our case report, the patient reported a history of sexual violence from the mother's intimate partner. Furthermore, the situation of vulnerability $2,6,9,10$ is perpetuated so women who have suffered any form of sexual abuse during their lifetime have a significant increase in the chances of having an unwanted pregnancy ${ }^{24}$.

The adolescent in the referred case report was not using any contraceptive method and refused to use longterm reversible methods during outpatient care, even under multidisciplinary guidance. It is known that the promotion of reproductive health ${ }^{16}$ after abortion brings satisfactory results both in reducing unsafe abortion ${ }^{17}$ and in the number of unplanned and unwanted pregnancies in cases of violence. Thus, information and awareness ${ }^{19}$ about various methods of post-abortion contraception ${ }^{16}$ and especially the facilitation of specialized services in women's health should be promoted ${ }^{9,21}$.

The benefits of legalizing abortion in Brazil in the cases provided by law ${ }^{18,20}$ show a reduction in the number of hospitalizations in public hospitals due to complications of abortion over the years and a reduction in maternal mortality ${ }^{7,25,26}$. This occurs in developed and developing countries especially when associated with a set of measures that guarantee knowledge about legalization in the population.

The legalization of abortion in Brazil ${ }^{18}$ is a controversial issue and is linked to aspects of religion and cul- ture ${ }^{27}$, hindering the search for health ${ }^{17}$ services and bringing harmful consequences to adolescent health ${ }^{2,3,7,28,29}$. However, social vulnerability is present in this context, where economic and educational levels interfere with access to safe and law ful abortion ${ }^{18,30-32}$.

The incidence of septic abortion varies widely among developing and developed countries ${ }^{6,7}$ and is also related to adolescence ${ }^{7,20}$. Serious infections resulted from unsafe abortion practices with consequent $\operatorname{sepsis}^{3,4,6,7,9}$ or severe hemorrhages ${ }^{3}$ may have a definitive repercussion on reproductive life, such as hysterectomy ${ }^{3,4,6}$ and sepsis in cases of foreign body insertion ${ }^{3,13}$. In our case, the patient developed severe pelvic infection, pelvic abscess, severe sepsis and needed intensive care.

The conservative management - preservation of the uterus - was timely, based on the patient's age and obstetrical history, to preserve her fertility and, in the future, provide an opportunity for a properly planned pregnancy.

Uterine perforation, hemorrhage, visceral injury, sepsis and shock after unsafe abortion can lead to death due to delayed presentation for appropriate medical treatment ${ }^{9}$. In our case report, the outcome was favorable for the patient due to the structure of care in a specialized environment in women's health and complexity level of high health service.

This case report helps guide clinical practice and reflects on the impact of veiled sexual violence and unsafe abortion on adolescent lives and on the health system.

\section{CONCLUSION}

The history of violence portrayed in this study reveals an attempt of abortion with self harm, revealing negative clinical repercussions and the health problems of the adolescent. This person has committed an abortion that does not fit into the abortion criteria provided by law. It also revealed the need for further discussion on the topic, highlighting health promotion practices against unsafe abortion.

\section{Competing interests}

The authors declare that they have no competing interests

\section{Acknowledgments}

Thanks to the gynecology sector of the Hospital das Clínicas of São Paulo and to the professionals who assisted in this case report.

\section{Authors' contributions}

ATMS, ESFF, GDS, CML, WSP, JMSJ, ECB and ICES participated in the acquisition of data and revision of the manuscript.

ATMS, GDS and ICES wrote the manuscript and carried out a bibliographical survey.

ESFF and ICES determined the design of the study. GDS and ATMS translation and English language. WSP, JMSJ, ECB and ICES review in English language.

All authors read and gave approval the version submitted for publication. 


\section{REFERENCES}

1. World Health Organization (WHO). Global and regional estimates of violence against women: prevalence and health effects of intimate partner violence and non-partner sexual violence. [cited 2016 Dec 10] Available from: http://apps.who.int/iris/bitstream/10665/85239/1/9789241564625_eng.pdf.

2. García-Moreno C, Zimmerman C, Morris-Gehring A, Heise L, Amin A, Abrahams N, et al. Addressing violence against women: a call to action. Lancet. 2015;385(9978):1685-95. DOI: http://dx.doi.org/10.1016/ S0140-6736(14)61830-4

3. Saultes TA, Devita D, Heiner JD. The Back Alley Revised: Sepsis after attempted Self-Induced Abortion. West J Emerg Med. 2009;10(4):278-80.

4. Nayak PK, Mitra S, Padma A, Agrawal S. Late presentation of unsafe abortion after 5 years of procedure. Case Reports Obstetr Gynecol. 2014;(2014). DOI: http://dx.doi.org/10.1155/2014/456017

5. Blake MT, Drezett J, Machi GS, Pereira VX, Raimundo RD, Oliveira FR, et al. Factors associated with the delay in seeking legal abortion for pregnancy resulting from rape. Int Arch Med. 2015;8. DOI: http://dx.doi. org/10.3823/1628

6. Sreelakshmi U, Thejaswini J, Bharathi T. The outcome of septic abortion: a tertiary care hospital experience. J Obstetr Ginaecol Índia. 2014;64(4):265-9. DOI: http://dx.doi.org/10.1007/s13224-014-0509-4

7. Azevedo WF, Diniz MB, Fonseca ES, Azevedo LM, Evangelista CB, et al. Complications in adolescent pregnancy: systematic review of the literature. Einstein (São Paulo). 2015;13(4):618-26. DOI: http://dx.doi. org/10.1590/S1679-45082015RW3127

8. Kind L, Orsini MLP, Nepomuceno V, Gonçalves L, Souza GA, Ferreira MFF. Primary healthcare and underreporting and (in)visibility of violence against women. Cad Saúde Pública. 2013;29(9):1805-15. DOI: http://dx.doi.org/10.1590/0102-311X00096312

9. Sama CB, Aminde LN, Angwafo FF. Clandestine abortion causing uterine perforation and bowel infarction in a rural area: a case report and brief review. BMC Res Notes. 2016;9:98. DOI: http://dx.doi.org/10.1186/ s13104-016-1926-5

10. Sorpreso ICE, Soares Junior JM, Baracat EC. Sexually vulnerable women: could reversible long-lasting contraception be the solution? Rev Bras Ginecol Obstet. 2015;37(9):395-6. DOI: http://dx.doi.org/10.1590/ SO100-720320150005456

11. Mattos IA, Lima IMSO. Motherhood and intrafamilial child sexual abuse: to guarante a protective embrace. J Hum Growth Dev. 2012;22(3):373-7. DOI: http://dx.doi.org/10.7322/jhgd.46709

12. Brasil. Ministério da Saúde. Secretaria de Atenção à Saúde. Departamento de Ações Programáticas Estratégicas. Linha de cuidado para a atenção integral à saúde de crianças, adolescentes e suas famílias em situações de violências. [cited 2016 Ouc 15] Available from: http://www.ensp.fiocruz.br/portalensp/ consultapublica/arquivos/1393133501.pdf

13. Grimes DA, Benson J, Singh S, Romero M, Ganatra B, Okonofua FE, et al. Unsafe abortion: the preventable pandemic. Lancet. 2006;368(9550):1908-19. DOI: http://dx.doi.org/10.1016/S0140-6736(06)69481-6

14. Jina R, Thomas LS. Health consequences of sexual violence against women. Best Pract Res Clin Obstet Gynaecol. 2013;27(1):15-26. DOI: http://dx.doi.org/10.1016/j.bpobgyn.2012.08.012

15. Diniz D, Medeiros M. Abortion in Brazil: a household survey using the ballot Box technique. Ciênc Saúde Coletiva. 2010;15(supl. 1):959-66. DOI: http://dx.doi.org/10.1590/S1413-81232010000700002

16. Figueiredo R, Bastos $S$, Telles $L$ J. Perfil da distribuição da contracepção de emergência para adolescentes em municípios do Estado de São Paulo. J Hum Growth Dev. 2012; 22(1):105-15. DOI: http://dx.doi. org/10.7322/jhgd.20058

17. Organização Mundial de Saúde (OMS). Abortamento seguro: orientação técnica e de políticas para sistemas de saúde. 2 ed. 2013. [cited 2016 Dec 10] Available from: http://apps.who.int/iris/bitstre am/10665/70914/7/9789248548437_por.pdf

18. Brasil. Câmara dos Deputados. Decreto n. ${ }^{\circ} 2848 / 40$, de 07 de dezembro de 1940. Código Penal Art. 124128. [cited 2016 Dec 10] Available from: https://www.jusbrasil.com.br/topicos/10624811/artigo-128-dodecreto-lei-n-2848-de-07-de-dezembro-de-1940.

19. Silva SA, Lucena KDT, Deininger LSC, Coelho HFC, Vianna RPT, Anjos UU. Analysis of Domestic Violence on Women's Health. J Hum Growth Dev. 2015;25(2):182-6. DOI: http://dx.doi.org/10.7322/jhgd.103009.

20. McCloskey LA. The Effects of gender-based violence on women's unwanted pregnancy and abortion. Yale J Biol Med. 2016;89(2):153-9.

21. Brasil. Ministério da Saúde. Política Nacional de Atenção Integral à Saúde da Mulher: princípios e diretrizes. Brasília: Ministério da Saúde. 2011.

22. Chalem E, Mitsuhiro SS, Ferri CP, Barros MCM, Guinsburg R, Laranjeira R. Teenager pregnancy: behavioral and socio-demographic profile of an urban Brazilian population. Cad Saúde Pública. 2007;23(1):17786. DOI: http://dx.doi.org/10.1590/S0102-311X2007000100019 
23. Milanez N, Oliveira AE, Barroso ADV, Martinelli KG, Esposti CDD, Santos Neto ET. Unwanted pregnancy and abortion attempt: practices and contexts. Sex Salud Soc. 2016;(22):129-46. DOI: http://dx.doi. org/10.1590/1984-6487.sess.2016.22.06.a

24. Heilborn ML. Heterossexualidades, contracepção e aborto: Uma pesquisa em quatro capitais latino-americanas. Sex Salud Soc. 2012;(12):127-34. DOI: http://dx.doi.org/10.1590/S1984-64872012000600006

25. Pallitto CC, García-Moreno C, Jansen HA, Heise L, Ellsberg M, Watts C, et al. Intimate partner violence, abortion, and unintended pregnancy: results from the WHO Multi-country Study on Women's Health and Domestic Violence. Int J Gynaecol Obstet. 2013;120(1):3-9. DOI: http://dx.doi.org/10.1016/j.ijgo.2012.07.003

26. Lukasse M, Laanpere M, Karro H, Kristjansdottir H, Schroll AM, Van Parys AS, et al. Pregnancy intendedness and the association with physical, sexual and emotional abuse - a European multi-country cross-sectional study. BMC Pregnancy Childbirth. 2015; 15:120. DOI: http://dx.doi.org/10.1186/s12884-015-0558-4

27. Henderson JT1, Puri M, Blum M, Harper CC, Rana A, Gurung G, et al. Effects of abortion legalization in Nepal, 2001-2010. Plos One. 2013;8(5):e64775. DOI: http://dx.doi.org/10.1371/journal.pone.0064775

28. Rocca CH, Puri M, Dulal B, Bajracharya L, Harper CC, Blum M, et al. Unsafe abortion after legalisation in Nepal: a cross-sectional study of women presenting to hospitals. BJOG. 2013;120(9):1075-83. DOI: http:// dx.doi.org/10.1111/1471-0528.1224229. Ogland CP, Verona AP. Religion and attitudes toward abortion and abortion policy in Brazil. J Sci Study Relig. 2011;50(4):812-21.

30. Noll JG, Trickett PK, Long JD, Negriff S, Susman EJ, Shalev I, et al. Childhood sexual abuse and early timing of puberty. J Adolescent Health. 2016;60(1):65-71. DOI: http://dx.doi.org/10.1016/j.jadohealth.2016.09.008

31. Bezerra IMP, Sorpreso ICE. Concepts and movements in health promotion to guide educational practices. J Hum Growth Dev. 2016;26(1):11-20. DOI: http://dx.doi.org/10.7322/jhgd.113709

32. Rocha MIB. A discussão política sobre aborto no Brasil: uma síntese. Rev Bras Est Pop. 2006;23(2):36974. DOI: http://dx.doi.org/10.1590/S0102-30982006000200011

This article is distributed under the terms of the Creative Commons Attribution 4.0 International License (http://creativecommons.org/licenses/by/4.0/), which permits unrestricted use, distribution, and reproduction in any medium, provided you give appropriate credit to the original author(s) and the source, provide a link to the Creative Commons license, and indicate if changes were made. The Creative Commons Public Domain Dedication waiver (http://creativecommons.org/publicdomain/zero/1.0/) applies to the data made available in this article, unless otherwise stated.

\section{Resumo}

Introdução: O aborto, mesmo quando previsto por lei nos casos de violência sexual, continua a ser praticado de maneira insegura, uma vez que as mulheres que experimentam essa violência não a relatam ou velam por vulnerabilidade social, institucional ou etária, como na adolescência.

Objetivo: Descrever as consequências clínicas do aborto inseguro e relatar essa experiência vivenciada bem como a violência sexual em situações de vulnerabilidade social e etária.

Método: Trata se de relato de caso clínico, com consentimento da paciente, ocorrido no ano de 2016 de uma adolescente, sexo feminino, 16 anos com antecedente pessoal de violência sexual de agressor íntimo. Admitida em serviço de saúde com diagnóstico de abdome agudo e aborto induzido em uso de antibioticoterapia.

Resultados: Laboratoriais revelaram proteína $C$ reativa alterada e presença de leucocitose, ultrassonografia apresentou massa heterogênica, tomográfica computadorizada evidenciou presença de corpo estranho cilíndrico em cavidade vaginal, intervenções cirúrgicas, infecções generalizadas, complicações clínicas.

Conclusão: A história de violência retratada nesse estudo revela uma tentativa de aborto com autolesão, desvelando repercussões clínicas negativas e os agravos à saúde da adolescente. Esta que cometeu um aborto que não se insere nos critérios de aborto previsto por lei. Revelou ainda a necessidade de maior discussão sobre o tema, destacando as práticas de promoção da saúde contra o aborto inseguro.

Palavras-chave: aborto, violência sexual, adolescente, aborto séptico. 